\title{
Cân nhắc về chi phí và nguồn lực trong thời đại mới: Tâm quan trọng của các mục tiêu "cộng hưởng"
}

\author{
Nguyễn Minh Hoàng \\ Trung tâm Nghiên cứu Xã hội Liên ngành \\ Trường đại học Phenikaa, Việt Nam \\ Nguyễn Quang Lộc \\ Trường đại học SP Jain School of Global Management, Úc \\ $26 / 09 / 2021$ \\ $* * * * *$
}

Vấn đề bảo tồn đa dạng sinh học và ngăn chặn việc nóng lên toàn cầu đã được đề cập rất nhiều trong các hội nghị và hiệp định quốc tế với quan điểm: phát triển xã hội cần đi kèm với việc bảo tồn tự nhiên. Xã hội loài người, nếu muốn hoạt động và phát triển bền vững, thì việc bảo vệ những giá trị của thiên nhiên là điều tiên quyết, vì chúng ta là một phần của hệ thống sinh thái tự nhiên. Đặc biệt hiện nay, những ảnh hưởng của biến đổi khí hậu, thiên tai như hạn hán, bão lũ ngày càng gây thiệt hại về người và tài sản, thậm chí ảnh hưởng nặng nề đến các nền kinh tế phụ thuộc vào ngành nông lâm nghiệp và thuỷ hải sản, như Việt Nam.

Việt Nam đang ngày càng chú trọng và đầu tư nhiều hơn vào các lĩnh vực chống biến đổi khí hậu và bảo tồn đa dạng sinh học. Tuy nhiên, việc kiểm soát dịch bệnh và phục hồi nền kinh tế sau đại dịch cũng quan trọng không kém và cần sự quan tâm đặc biệt của chính phủ. Nguồn lực hạn chế trong khi lại có quá nhiều vấn đề phải cân nhắc đang là trở ngại rất lớn cho các nhà hoạch định chính sách. Do đó, chúng ta cần một cách tiếp cận mới có thể tăng tính hiệu quả trong việc sử dụng chi phí và nguồn lực nhưng vẫn góp phần đạt được các mục tiêu về kinh tế, xã hội, và môi trường.

Mới đây, bài báo "Regional scalable priorities for national biodiversity and carbon conservation planning in Asia" chỉ ra rằng các quốc gia châu Á có thể đạt được mục tiêu bảo tồn đa dạng sinh học và giảm lượng khí carbon cùng lúc bằng cách tập trung vào bảo vệ các khu vực trọng điểm có tính cộng hưởng [1]. Các khu vực trọng điểm có tính cộng hưởng nghĩa là các khu vực vừa có độ đa dạng sinh học cao và khả năng lưu trữ carbon tốt. Theo các nhà khoa học, nếu như tập trung vào các khu vực trọng điểm có tính cộng hưởng, thì bảo tồn 30\% diện tích đất châu Á sẽ giúp bảo tồn hơn $70 \%$ các loài động vật có xương sống trên cạn và tồn trữ được từ 2.3 đến 3.6 trăm tỷ tấn carbon. 
Từ kết quả này có thể thấy được, việc hoạch định các mục tiêu cộng hưởng để giải quyết cùng lúc hai mục tiêu (như đa dạng sinh học và giảm thiểu khí carbon) là rất quan trọng, vì điều đấy giúp tối ưu hóa lợi ích và giảm thiểu chi phí nguồn lực. Ngoài ra, việc đặt các mục tiêu cộng hưởng sẽ giúp chúng ta tránh các giải pháp mang tính "cục bộ", gây thiệt hại về lâu dài. Ví dụ, nếu chỉ ưu tiên mục tiêu giảm lượng khí carbon sẽ gây mất đa dạng sinh học. Một số loài cây có khả năng hấp thụ khí carbon nhiêuu hơn các loài cây khác, nếu tăng diện tích trông loài cây này thì cũng đồng nghĩa với việc diện tích cho các loài cây khác sẽ giảm đi, gây mất độ đa dạng sinh học $[2,3]$. Việc mất đi độ đa dạng sinh học sau đấy sẽ dẫn đến giảm năng lực hấp thụ khí carbon (v.d. dịch bệnh và côn trùng có thể phát triển nhanh ở vùng có độ đa dạng sinh học thấp, dẫn đến hiện tượng cây bị bệnh hoặc chết hàng loạt) $[4,5]$.

Không chỉ riêng bảo tồn đa dạng sinh học và giảm lượng khí carbon, các mục tiêu cộng hưởng còn có thể bao gồm nhiều khía cạnh khác, như giảm thiểu nguy cơ xảy ra đại dịch. Trong một nghiên cứu tại khu vực rừng ven biển tại Brazil, nhóm nhà khoa học đã nhận thây $9 \%$ dơi được tìm thây ở khu đất bên cạnh khu dân cư có chứa hơn 16 loại virus nguy hiểm, bao gồm cả virus Corona và Hantavirus [6]. Ngược lại, ở những vùng rừng không chịu tác động của con người thì số lượng dơi chứa virus giảm hơn một nửa, và số virus trong mỗi cá thể giảm chỉ còn 6 loại. Điều này cho thấy khi độ đa dạng sinh học của các loài tăng cao, số lượng động vật ủ bệnh (chứa virus) sẽ giảm đi.

Nguyên nhân chính có thể là do trong hệ thống sinh thái tự nhiên tồn tại định luật cân bằng sinh học. Khi những cá thể chứa virus và suy yếu, chúng sẽ bị loại trừ ra khỏi quân xã khi bị các đối thủ cạnh tranh hoặc bị những động vật săn mồi tiêu diệt. Những nơi có độ đa dạng sinh học cao thường sẽ có nhiều cá thể khoẻ mạnh hơn, và giảm thiểu nguy cơ lây lan các loại virus khác. Khi con người tác động đến môi trường, đặc biệt là làm suy giảm độ đa dạng sinh học, những hệ quả xấu gây tác động ngược lại là điều không thể tránh khỏi. Đặc biệt hiện nay, đa số những loài dơi thường trú ngụ ở các toà nhà, nơi mà chúng không bị kìm hãm bởi hệ sinh thái tự nhiên và luật cân bằng sinh học. Điều này là nguy cơ tiềm ẩn dịch bệnh cho loài người và ảnh hưởng xấu cho toàn xã hội. Những hoạt động chuyển đổi mục đích rừng hay khai thác tài nguyên rừng nên được cân nhắc kĩ lưỡng vì đó chính là nguồn gián tiếp hoặc trực tiếp gây ra các đại dịch [7]. Việc phá huỷ rừng tự nhiên để đổi lấy lợi ích kinh tế, nhưng hệ quả là gây ra dịch bệnh cho người dân Kenya có thể là một ví dụ điển hình trong trường hợp này [8].

Khó khăn trong các thập kỷ tiếp theo không chỉ bó gọn trong vấn đề về kinh tế, môi trường, mà còn bao gồm cả các vấn đề liên quan đến y tế cộng đồng . Đặc biệt kể từ lúc đại dịch Covid-19 bùng phát, các chính phủ cần phải dành nhiều tài nguyên cho việc 
chống dịch và khôi phục nền kinh tế. Điều này tạo ra gánh nặng về nguồn lực và chi phí cực lớn cho các quốc gia trên thế giới, đặc biệt là với một nước đang trong quá trình công nghiệp hóa và hiện đại hóa như Việt Nam [9]. Vì thế, đặt ra các mục tiêu cộng hưởng là rất cấp thiết ở thời điểm này để vừa cắt giảm chi phí mà vẫn đạt được các mục tiêu quốc gia về phát triển bền vững.

Tuy nhiên, để đề ra được các mục tiêu cộng hưởng đúng và hiệu quả thì chúng ta cần chú trọng hơn đến các góc nhìn mang tính liên ngành [10]. Đặc biệt là trong nghiên cứu khoa học, vì bằng chứng khoa học, như các kết quả nghiên cứu trình bày phía trên, đem lại giá trị tham khảo rất lớn cho việc hoạch định và triển khai chính sách $[11,12]$. Ngoài ra, khi tính liên ngành được chú trọng thì sự đồng bộ hóa trong bộ máy quản lý, giám sát, và thẩm định cũng cần được tăng cường để tránh chồng chéo công việc và giảm chi phí ma sát không đáng có.

\section{Nguồn tham khảo}

[1] Zhu L, et al. (2021). Regional scalable priorities for national biodiversity and carbon conservation planning in Asia. Science Advances, 7(35), 4261.

[2] Lewis SL, Wheeler CE, Mitchard ETA, Koch A. (2019). Restoring natural forests is the best way to remove atmospheric carbon. Nature, 568(7750), 25-28.

[3] Lindenmayer DB, et al. (2012). Avoiding bio-perversity from carbon sequestration solutions. Conservation Letters, 5(1), 28-36.

[4] Woodley S, Bhola N, Maney C, Locke H. (2019). Area-based conservation beyond 2020: A global survey of conservation scientists. Parks, 25(2), 19-30.

[5] Maxwell SL, et al. (2019). Degradation and forgone removals increase the carbon impact of intact forest loss by 626. Science Advances, 5(10). doi: 10.1126/sciadv.aax2546.

[6] Ramos A. (2016). Scientists scour the Amazon for pathogens that could spark the next pandemic. Science. Trích xuất tại: https://www.science.org/content/article/scientists-scour-amazon-pathogens-couldspark-next-pandemic

[7] Burkett-Cadena ND, Vittor AY. (2018). Deforestation and vector-borne disease: Forest conversion favors important mosquito vectors of human pathogens. Basic and Applied Ecology, 26, 101-110.

[8] Afrane YA, Little TJ, Lawson BW, Githeko AK, Yan G. (2008). Deforestation and Vectorial Capacity of Anopheles gambiae Giles Mosquitoes in Malaria Transmission, Kenya. Emerging Infectious Diseases, 14(10), 1533-1538.

[9] Chính PM, Hoàng VQ. (2021). Kinh tế Việt Nam: Thăng trầm và đột phá. Nxb Chính trị Quốc gia, Hà Nội. 
[10] Vuong QH. (2021). The semiconducting principle of monetary and environmental values exchange. Economics and Business Letter, 10(3), 284-290.

[11] Hoàng NM. (2021). Dịch bệnh, đói nghèo, thiên tai: Con đường nào cho chúng ta vượt qua khó khăn? Kinh tế và Dự báo. Trích xuất tại: https://kinhtevadubao.vn/dich-benh-doi-ngheo-thien-tai-con-duong-nao-chochung-ta-vuot-qua-kho-khan-19288.html

[12] Vuong QH. (2018). The (ir)rational consideration of the cost of science in transition economies. Nature Human Behaviour, 2, 5. 